\title{
Jugular arginine infusion relieves lipopolysaccharide-triggered inflammatory stress and improves immunity status of lactating dairy cows
}

\author{
F. F. Zhao, ${ }^{* 1}$ T. Y. Wu, $\dagger^{1}$ H. R. Wang, ${ }^{* 2}$ L. Y. Ding, ${ }^{*}$ Gulzar Ahmed, ${ }^{*}$ H. W. Li, ${ }^{*}$ W. Tian, ${ }^{*}$ and Y. Z. Shen ${ }^{*}$ \\ *Laboratory of Metabolic Manipulation of Herbivorous Animal Nutrition, College of Animal Science and Technology, Yangzhou University, \\ Yangzhou 225009, China \\ †Bright Farming Co. Ltd., Shanghai 200436, China
}

\section{ABSTRACT}

The objective of this study was to evaluate the effects of jugular L-Arg infusion on performance and immune function during lipopolysaccharide (LPS)-induced inflammation of lactating dairy cows. Eight Holstein cows (multiparous, $608.8 \pm 31.5 \mathrm{~kg}$ ) at mid-lactation were randomly assigned to 5-d jugular infusions of control (saline), Arg ( $3 \mathrm{~g} / \mathrm{h})$, LPS $(0.033 \mu \mathrm{g} / \mathrm{kg}$ per $\mathrm{h})$, and LPS $+\operatorname{Arg}(0.033 \mu \mathrm{g} / \mathrm{kg}$ per h of LPS and 3 $\mathrm{g} / \mathrm{h}$ of $\mathrm{Arg}$ ) in a replicated $4 \times 4$ Latin square design with 4 infusion periods separated by 10-d noninfusion periods. Jugular solutions of saline, Arg, LPS, and LPS + Arg were continuously infused using peristaltic pumps for approximately $6 \mathrm{~h} / \mathrm{d}$ during infusion periods. Milk yield was measured on each day of the infusion period. Milk samples were obtained on the last $2 \mathrm{~d}$ of each infusion period, and blood samples were obtained on the last day of each infusion period before infusion $(0 \mathrm{~h})$ and at 3 and $6 \mathrm{~h}$. We found that the jugular LPS infusion significantly increased serum concentrations of IL-1 $\beta$, IL-6, tumor necrosis factor, inducible nitric oxide synthase, and lipopolysaccharide binding protein, whereas Arg attenuated the increase in IL-6 and inducible nitric oxide synthase levels and tended to decrease the lipopolysaccharide binding protein level. Arginine alleviated the decrease in dry matter intake and milk fat yield and the increase of somatic cell count induced by LPS. Total casein in milk was decreased during the LPS-induced inflammation period, and jugular Arg infusion significantly increased the content of total casein. In contrast, lactalbumin in milk increased during the LPS-induced inflammation period, whereas jugular Arg infusion significantly decreased the content of lactalbumin. The concentrations of plasma Gly, Thr, Ile, Leu, Arg, Phe, and total free

\footnotetext{
Received September 18, 2017.

Accepted February 24, 2018.

${ }^{1}$ These authors contributed equally to this work.

${ }^{2}$ Corresponding author: hrwang@yzu.edu.cn
}

AA were significantly decreased by LPS treatment, but Arg attenuated this tendency. These results indicated that jugular Arg infusion $(18 \mathrm{~g} / \mathrm{d})$ has protective effects on relieving inflammatory stress and improving immunity status triggered by LPS. In conclusion, Arg could attenuate inflammatory stress and improve milk performance of lactating dairy cows. This protective effect may be due to the ability of Arg to suppress LPS effects and improve immunity status.

Key words: arginine, lipopolysaccharide, inflammatory stress, immunity, dairy cow

\section{INTRODUCTION}

High-yielding dairy cattle are often fed concentratebased diets to meet their energy demands. However, feeding excessively high grain diets increased the concentration of free ruminal LPS due to increased lyses of gram-negative bacteria cells, resulting from a rise in rumen acidity (Khafipour et al., 2009; Plaizier et al., 2012). Extensive research has shown that the LPS accumulation in the rumen can translocate into the peripheral blood circulation (Sato, 2015; Bilal et al., 2016). Once translocated, LPS in blood circulation interacts with lipopolysaccharide binding protein (LBP) to augment autologous activity (Plaizier et al., 2012). Subsequently, immunoactivation and systemic inflammatory responses began, after the LPS-LBP complex was transferred to cluster of differentiation 14 (CD14) and recognized by immune cells. This inflammatory response can be experimentally modeled by LPS administration. It has been reported that LPS intravenously infused into systemic circulation was recognized by immune cells, and then elicited the production of inflammation markers such as IL-1, IL-6, tumor necrosis factor (TNF- $\alpha$ ), and the secretion of acute phase proteins such as LBP in serum (Emmanuel et al., 2008; Ametaj et al., 2010; Zhou et al., 2014). The inflammatory responses induced by LPS markedly disrupted the nutrient metabolism and changed the feed intake behavior in dairy cows (Zebeli and Metzlerzebeli, 2012). 
Kvidera et al. (2017) also reported that intravenously LPS-challenged dairy cows had increased blood glucose consumption by activated immune cells, accompanied by anorexia. During the last decade, extensive research has shown that DMI decreased when dairy cows were given jugular LPS infusion (Waldron et al., 2003; Aditya et al., 2017). In addition, LPS was associated with declines in milk production and quality observed by Dong et al. (2011) and Kobayashi et al. (2013).

Arginine has been shown to be a powerful mediator of multiple metabolic pathways that are vital to inflammation and immune response (Satriano, 2004; Wu, 2013). Arginine is the sole substrate for the production of nitric oxide and the precursor for the synthesis of polyamines, proline, and agmatine, which are important immune modulators. Polyamines are involved in cell division, DNA replication, and regulation of the cell cycle. Proline is responsible for protecting lymphocytes from apoptosis, stimulating cell growth and antibody production. Agmatine can affect the generation and the intracellular concentrations of polyamines. Despite the fact that Arg can be synthesized by the dairy cow, it is normally considered an EAA during inflammatory conditions (Doepel and Lapierre, 2011). In this case, Arg consumption is enhanced, while de novo and exogenous supplies are decreased, as a result of a variety of metabolic and immunologic alterations (Luiking et al., 2009; Wijnands et al., 2015). This evidence may indicate that the inflammation is often associated with Arg deficiency. Therefore, the strategy to supplement Arg has been deemed an effective measure to attenuate inflammatory stress when cows are exposed to a high-grain diet. It has been reported that exogenous administration of L-Arg decreased the production of IL-1 $\beta$, IL-6, and TNF- $\alpha$ induced by LPS in a rat model (Mohamed et al., 2015). Furthermore, it has been demonstrated that Arg supplementation or intravenous infusion had a positive effect on inflammation and immune response in weaned pigs (Zhu et al., 2013; Pi et al., 2014), broiler chickens (Tan et al., 2014), fish (Jiang et al., 2015), and mice (Calkins et al., 2001). To date, little research has been focused on these potentially protective effects in lactating dairy cows. Our previous in vitro studies showed that Arg effectively attenuated the inflammation induced by LPS in bovine mammary epithelial cells via inhibiting NF- $\kappa$ B signaling pathways (Wu et al., 2016).

Therefore, we hypothesized that Arg could relieve inflammatory stress and improve the immunity status in lactating dairy cows. The objective of the current study was to investigate the effects of Arg on inflammatory responses and production performance, including DMI, milk yield and composition, cytokines, inducible nitric oxide synthase (iNOS), LBP, serum metabolite profiles, and the plasma amino acid profiles in lactating dairy cows experimentally challenged with LPS.

\section{MATERIALS AND METHODS}

\section{Animals and Housing}

All experimental animals received care according to the Guide for the Care and Use of Laboratory Animals by the Chinese Academy of Sciences (2013). Holstein cows at mid lactation (multiparous), averaging 201 DIM and $608.8 \mathrm{~kg}$ of BW, were used for this study. Cows were housed in a freestall barn with constant access to water and feed. A common TMR (Table 1) was mixed at $0800 \mathrm{~h}$ and offered daily during 15 -d periods. Cows were fed ad libitum to achieve a minimum of $5 \%$ refusals on as-fed basis. Diets were formulated to meet all nutrient requirements for a $600-\mathrm{kg}$ Holstein cow producing $20 \mathrm{~kg}$ of milk containing $4.0 \%$ milk fat and $3.0 \%$ milk protein as evaluated according to NRC (2001). The daily feed intake of each cow was individually measured throughout the experimental periods. Cows were milked twice daily at 0530 and $1730 \mathrm{~h}$.

Table 1. Ingredients, chemical composition, and nutrient contents of the experimental diets

\begin{tabular}{|c|c|}
\hline Item (\% of DM, unless noted) & Value \\
\hline \multicolumn{2}{|l|}{ Ingredient } \\
\hline Chinese wildrye hay & 8.50 \\
\hline Alfalfa hay & 15.30 \\
\hline Corn silage & 31.20 \\
\hline Corn & 20.50 \\
\hline Cottonseed meal & 2.00 \\
\hline Soybean meal & 11.47 \\
\hline DDGS $^{1}$ & 9.40 \\
\hline $\mathrm{NaCl}$ & 1.10 \\
\hline Premix $^{2}$ & 0.50 \\
\hline Total & 100.00 \\
\hline \multicolumn{2}{|l|}{ Nutrient level $^{3}$} \\
\hline $\mathrm{NE}_{\mathrm{L}}(\mathrm{Mcal} / \mathrm{kg})$ & 1.61 \\
\hline $\mathrm{CP}$ & 14.96 \\
\hline NDF & 32.27 \\
\hline $\mathrm{ADF}$ & 20.14 \\
\hline NFC & 30.99 \\
\hline Ether extract & 3.02 \\
\hline Ash & 8.60 \\
\hline $\mathrm{Ca}$ & 0.90 \\
\hline $\mathrm{P}$ & 0.61 \\
\hline Concentrate:forage & $45: 55$ \\
\hline $\mathrm{NFC} / \mathrm{NDF}$ & 0.96 \\
\hline
\end{tabular}

${ }^{1}$ DDGS $=$ distillers dried grains with solubles.

${ }^{2}$ One kilogram of premix contains the following: $\mathrm{Cu}, 3,125 \mathrm{mg}$; Fe, 5,500 mg; Mn, 4,980 mg; Zn, 17,500 mg; Co, $6.2 \mathrm{mg}$; I, $6.25 \mathrm{mg}$; vitamin A, 1,500,000 IU; vitamin D, 31,250,000 IU; vitamin $\mathrm{E}_{3}, 125 \mathrm{mg}$; niacin, 4,500 $\mathrm{mg}$; and choline, 125,000 $\mathrm{mg}$.

${ }^{3} \mathrm{NE}_{\mathrm{L}}$ and NFC were calculated in reference to NRC (2001), whereas the other nutrition levels were measured values. 


\section{Treatments}

The animals were randomly assigned to 1 of 4 treatments in a replicated $4 \times 4$ Latin square design. The treatments were randomly distributed as jugular infusion of (1) control (saline), (2) Arg (Arg, $3 \mathrm{~g} / \mathrm{h}$ ), (3) LPS $(0.033 \mu \mathrm{g} / \mathrm{kg}$ per $\mathrm{h})$, and (4) LPS + Arg (0.033 $\mu \mathrm{g} / \mathrm{kg}$ per $\mathrm{h}$ of LPS and $3 \mathrm{~g} / \mathrm{h}$ of Arg). The Arg and LPS were dissolved in double-distilled water. The LPS (Escherichia coli O55:B5) was purchased from SigmaAldrich (lot 2880, St. Louis, MO). Arginine (purity $>99 \%$ ) was purchased from Ajinomoto (Tokyo, Japan). The $\mathrm{pH}$ of the stock solution was adjusted to 7.5 with $\mathrm{HCl}$ in a daily volume of $1 \mathrm{~L} / \mathrm{cow}$. Then the solutions were filtered through $0.22-\mu \mathrm{m}$ membrane filters (Millipore, Billerica, MA) into sterile bottles and stored for no more than $2 \mathrm{~d}$ at $4^{\circ} \mathrm{C}$. On d 1 of each treatment period, cows were aseptically fitted with indwelling jugular polyvinyl chloride catheters (173 mm:1.2 mm i.d:2.0 mm o.d.; Jiangxi Huali Medical Instrument, Ganzhou, China). Infusions were delivered at a rate of $2.7 \mathrm{~mL} /$ min for approximately $6 \mathrm{~h}$ each day using peristaltic pumps (Longer BT100-1 L, Baoding, China). Every day during the trial, infusions began 30 min after the morning milking, and the catheters were flushed and filled with saline containing $100 \mathrm{U} / \mathrm{mL}$ of heparin after the infusion to prevent coagulation. Treatments were 5 -d jugular infusions of $0.9 \%$ saline (Baxter, Deerfield, IL) as the control treatment, Arg, LPS, and LPS + Arg. Treatment periods were separated by $10-\mathrm{d}$ interval periods to minimize carryover effects.

\section{Milk Sampling and Analyses}

Milk yield was recorded at each milking and sampled on the last $2 \mathrm{~d}$ of each infusion period. Daily milk samples were mixed with a ration of $6: 4$ as morning $(0530$ h) and night $(1730 \mathrm{~h})$ for each cow. The same amount of the milk sample from the last $2 \mathrm{~d}$ of each infusion period was mixed and analyzed. A total of $100 \mathrm{~mL}$ of milk sample was collected and mixed with $20 \%$ potassium dichromate to store at $4^{\circ} \mathrm{C}$ for fat, protein, lactose, TS, somatic cells, and urea nitrogen analysis by using the Berthelot procedure (ChemSpec 150 Analyzer, Bentley Instruments, Chaska, MN). An additional 20-mL milk sample without $20 \%$ potassium dichromate was stored at $-20^{\circ} \mathrm{C}$ for the protein composition analysis after centrifuging $\left(1,801 \times \mathrm{g}\right.$, at $4^{\circ} \mathrm{C}$ for $\left.10 \mathrm{~min}\right)$ to remove milk fat. The contents of $\alpha_{\mathrm{S1}^{-}}, \alpha_{\mathrm{S} 2^{-}}, \beta-$, and $\kappa-\mathrm{CN}$, lactalbumin, $\operatorname{Ig} \mathrm{A}, \operatorname{Ig} \mathrm{G}$, and $\operatorname{IgM}$ were measured by ELISA kits (MyBioSource Inc., San Diego, CA; catalog no. MBS7606672, MBS7208022, MBS455015, MBS453025, MBS058425, MBS564143, MBS285353, and MBS282896, respectively). The examination steps were carried out according to the manufacturer's protocol, and the optical density of each well was read at $450 \mathrm{~nm}$. The intra-assay coefficients of variation were all less than $7.52 \%$, and the inter-assay coefficients of variation were all less than $14.16 \%$.

\section{Blood Sampling and Analyses}

On d 5 of each infusion period, blood samples were collected into $10-\mathrm{mL}$ heparinized vacuum tubes (Becton Dickinson and Company, Franklin Lakes, NJ) and 10-mL serum tubes (Becton Dickinson and Company) from the jugular vein before infusion $(0 \mathrm{~h})$ and at 3 and $6 \mathrm{~h}$. Blood samples of heparinized tubes were immediately centrifuged $\left(10 \mathrm{~min}, 1,801 \times g, 4^{\circ} \mathrm{C}\right)$, and plasma aliquot of period and cow was pooled by 0,3 , and 6 $\mathrm{h}$ time points and stored at $-20^{\circ} \mathrm{C}$ for the analysis of AA concentrations. Samples of serum tubes were centrifuged $\left(10 \mathrm{~min}, 1,801 \times g, 4^{\circ} \mathrm{C}\right) 2 \mathrm{~h}$ after collection, and serum aliquot of period and cow was pooled by 0,3 and $6 \mathrm{~h}$ time points and stored at $-20^{\circ} \mathrm{C}$ for the analysis of IL-1 $\beta$, IL-6, TNF- $\alpha$, iNOS, LBP, total protein (TP), alanine aminotransferase (ALT), aspartate aminotransferase (AST), urea, and glucose. A third 2-mL blood sample was collected into an EDTA-K3 anticoagulative vacuum tube (Becton Dickinson and Company), kept refrigerated at $4^{\circ} \mathrm{C}$, and analyzed on the same or next day for total white blood cells (WBC) using an automated hematology analyzer Sysmex K4500 (TOA Medical Electronics Co., Kobe, Japan). Blood samples were also obtained at 9 and $10 \mathrm{~d}$ of the noninfusion period preceding each infusion to determine whether or not carry-over effects of treatments occurred.

Plasma AA concentrations were determined after plasma deproteinization in a sulfosalicylic acid solution combined with an internal standard (norvaline). Chromatographic separation of AA was performed on a HPLC (LC-15C, Shimadzu, Kyoto, Japan), according to the method of Moore and Stein (1954).

The serum concentrations of IL-1 $\beta$, IL- 6 , and TNF- $\alpha$ were determined using mouse IL- $1 \beta$ and TNF- $\alpha$ ELISA kits by reference to $\mathrm{Wu}$ et al. (2016) and bovine IL-6 ELISA kit (catalog no. DY401, MTA00, and DY8190, R\&D Systems, Minneapolis, MN). The intra-assay and inter-assay coefficients of variation were less than $5.45 \%$ and less than $13.15 \%$. The serum concentrations of LBP and iNOS were determined with an ELISA kit (catalog no. MBS103364, MyBioSource Inc.) and commercial diagnostic kit (catalog no. A014-1, Nanjing Jiancheng Bioengineering Institute, Nanjing, China). The optical density at 450 and $530 \mathrm{~nm}$ was measured on a microplate spectrophotometer (ELx 800, BioTek 
Instruments, Winooski, VT). The intra-assay and interassay coefficients of variation were less than $4.49 \%$ and less than $5.32 \%$.

The concentrations of TP, ALT, AST, urea, and glucose were assayed by commercial kits (catalog no. 000020140, 000020000, 000020010, 000020070, and 000020100, BioSino Bio-Technology \& Science Inc., Beijing, China) with a Hitachi 7060 automated biochemical analyzer (Hitachi Group, Tokyo, Japan). The intra-assay and inter-assay coefficients of variation were less than $6.57 \%$ and less than $10.41 \%$, respectively.

\section{Statistical Analysis}

The data were analyzed using general linear model procedures of SAS (version 9.2, SAS Institute Inc., Cary, NC):

$$
\mathrm{Y}_{\mathrm{ijk}}=\mu+\mathrm{T}_{\mathrm{i}}+\mathrm{P}_{\mathrm{j}}+\mathrm{C}_{\mathrm{k}}+\mathrm{e}_{\mathrm{ijk}},
$$

where $\mathrm{Y}_{\mathrm{ijk}}=$ response variable value of the $\mathrm{kth}$ cow subjected to the ith treatment in the jth period, $\mu$ is the grand mean, $\mathrm{T}_{\mathrm{i}}=$ fixed effect of the ith treatment ( $\mathrm{i}=$ control, Arg, LPS, and LPS + Arg), $\mathrm{P}_{\mathrm{j}}=$ random effect of the jth period $(\mathrm{j}=1,2,3$, and 4$), \mathrm{C}_{\mathrm{k}}=$ random effect of the kth cow, and $e_{i j k}=$ the random error. Period $\times$ treatment interactions were initially included and found to be very small, and they were accordingly excluded in the final analyses. Treatment differences were determined by the Duncan multiple comparison procedure and were considered significant if $P \leq 0.05$ and as a trend for $0.05<P \leq 0.10$. All data are reported as the means with pooled standard errors (SEM). Car- ryover effects of treatments were tested using the same model on the dependent variables measured during the noninfusion periods preceding each infusion period. No differences were found for serum cytokine-dependent variables between the 4 noninfusion periods. The data are presented in Table 4.

\section{RESULTS}

\section{Feed Intake and Milk Performance}

The DMI and the milk performance data are presented in Table 2. The DMI of LPS treatment was significantly lower than that of the saline, Arg, and LPS + Arg treatments $(P<0.05)$. Milk yield and lactose yield of LPS + Arg treatment were in between Arg and LPS treatments. Milk protein yield and milk fat yield were significantly decreased in the LPS treatment than the saline treatment $(P<0.05)$. The LPS + Arg treatment significantly increased its milk fat yield $(P$ $<0.05)$ compared with the LPS treatment. Infusions of LPS significantly decreased fat percentage compared with the saline treatment $(P<0.05)$. The tendency of increased fat percentage was obtained by the LPS + Arg treatment compared with that of LPS. Milk SCC significantly increased in the LPS-challenged treatment $(P<0.05)$ compared with the saline, Arg, and LPS + Arg treatments $(P<0.05)$. No significant difference was observed in the percentage of milk protein and lactose, SNF, and MUN $(P>0.05)$ among all the treatments.

Milk Protein Composition. The milk protein composition data are summarized in Table 3. Total casein content was lowest $(P<0.05)$ in the LPS treat-

Table 2. Effects of jugular arginine infusion on feed intake and milk production and composition during LPSinduced inflammation of lactating cows

\begin{tabular}{lcccccc}
\hline & \multicolumn{5}{c}{ Experimental treatment } \\
\cline { 2 - 5 } Item & Saline & Arg & LPS & LPS + Arg & SEM & $P_{\text {-value }}{ }^{2}$ \\
\hline DMI (kg/d) & $16.62^{\mathrm{a}}$ & $16.45^{\mathrm{a}}$ & $14.06^{\mathrm{b}}$ & $16.14^{\mathrm{a}}$ & 0.79 & 0.013 \\
Milk production & & & & & & \\
Milk yield (kg/d) & $18.81^{\mathrm{ab}}$ & $20.77^{\mathrm{a}}$ & $15.34^{\mathrm{b}}$ & $19.02^{\mathrm{ab}}$ & 1.02 & 0.032 \\
Protein yield (g/d) & $549.28^{\mathrm{a}}$ & $600.80^{\mathrm{a}}$ & $452.94^{\mathrm{b}}$ & $539.44^{\mathrm{ab}}$ & 45.52 & 0.018 \\
Fat yield (g/d) & $675.15^{\mathrm{a}}$ & $794.45^{\mathrm{a}}$ & $466.52^{\mathrm{b}}$ & $651.13^{\mathrm{a}}$ & 70.04 & 0.001 \\
Lactose yield (g/d) & $865.91^{\mathrm{ab}}$ & $935.87^{\mathrm{a}}$ & $724.02^{\mathrm{b}}$ & $834.50^{\mathrm{ab}}$ & 88.64 & 0.122 \\
SCC (×104 cells/mL) & $31.58^{\mathrm{b}}$ & $38.01^{\mathrm{b}}$ & $292.16^{\mathrm{a}}$ & $106.85^{\mathrm{b}}$ & 61.19 & 0.001 \\
Protein (\%) & 2.91 & 2.90 & 3.01 & 2.86 & 0.10 & 0.477 \\
Fat (\%) & $3.62^{\mathrm{a}}$ & $3.83^{\mathrm{a}}$ & $2.94^{\mathrm{b}}$ & $3.40^{\mathrm{ab} *}$ & 0.23 & 0.005 \\
Lactose (\%) & 4.60 & 4.50 & 4.40 & 4.40 & 0.16 & 0.266 \\
SNF (\%) & 14.02 & 13.98 & 13.07 & 13.59 & 0.51 & 0.246 \\
Milk urea N (\%) & 13.52 & 14.35 & 13.60 & 13.44 & 1.91 & 0.961 \\
\hline
\end{tabular}

${ }^{a, b}$ Values within a row with different superscripts differed $(P<0.05)$ or tended $\left({ }^{*} P<0.10\right)$ to differ from the LPS treatment.

${ }^{1}$ Treatments: control (saline), Arg $(3 \mathrm{~g} / \mathrm{h})$, LPS $(0.033 \mu \mathrm{g} / \mathrm{kg}$ per h), and LPS + Arg $(0.033 \mu \mathrm{g} / \mathrm{kg}$ per h of LPS and $3 \mathrm{~g} / \mathrm{h}$ of Arg).

${ }^{2}$ Probability of a difference among the 4 treatments: control (saline), Arg, LPS, and LPS + Arg. 
Table 3. Effects of jugular Arg infusion on casein and lactoprotein during LPS-induced inflammation of lactating cows

\begin{tabular}{|c|c|c|c|c|c|c|}
\hline \multirow[b]{2}{*}{ Item } & \multicolumn{4}{|c|}{ Experimental treatment ${ }^{1}$} & \multirow[b]{2}{*}{ SEM } & \multirow[b]{2}{*}{$P$-value ${ }^{2}$} \\
\hline & Saline & Arg & LPS & LPS + Arg & & \\
\hline Total casein $(\mathrm{g} / \mathrm{L})$ & $24.33^{\mathrm{a}}$ & $24.43^{\mathrm{a}}$ & $22.19^{\mathrm{c}}$ & $23.16^{\mathrm{b}}$ & 0.43 & $<0.001$ \\
\hline$\alpha_{\mathrm{S}_{1}-\mathrm{CN}}(\mathrm{g} / \mathrm{L})$ & $6.95^{\mathrm{ab}}$ & $7.05^{\mathrm{a}}$ & $6.33^{\mathrm{b}}$ & $6.58^{\mathrm{ab}}$ & 0.30 & 0.082 \\
\hline$\alpha_{\mathrm{S} 2}-\mathrm{CN}(\mathrm{g} / \mathrm{L})$ & $3.60^{\mathrm{a}}$ & $3.93^{\mathrm{a}}$ & $3.19^{\mathrm{b}}$ & $3.38^{\mathrm{ab}}$ & 0.24 & 0.131 \\
\hline$\beta-\mathrm{CN}(\mathrm{g} / \mathrm{L})$ & $11.70^{\mathrm{a}}$ & $11.38^{\mathrm{ab}}$ & $10.92^{\mathrm{b}}$ & $11.25^{\mathrm{ab}}$ & 0.29 & 0.095 \\
\hline$\kappa-\mathrm{CN}(\mathrm{g} / \mathrm{L})$ & 2.07 & 2.07 & 1.94 & 1.95 & 0.07 & 0.138 \\
\hline Lactalbumin $(\mathrm{g} / \mathrm{L})$ & $3.25^{\mathrm{c}}$ & $3.30^{\mathrm{c}}$ & $4.20^{\mathrm{a}}$ & $3.60^{\mathrm{b}}$ & 0.12 & $<0.001$ \\
\hline $\operatorname{IgA}(\mathrm{mg} / \mathrm{L})$ & $123.84^{\mathrm{c}}$ & $130.45^{\mathrm{bc}}$ & $145.65^{\mathrm{a}}$ & $138.83^{\mathrm{ab}}$ & 5.60 & 0.005 \\
\hline IgG (mg/L) & 571.90 & 575.25 & 647.93 & 600.56 & 42.58 & 0.283 \\
\hline $\operatorname{IgM}(\mathrm{mg} / \mathrm{L})$ & $103.24^{\mathrm{b}}$ & $112.33^{\mathrm{ab}}$ & $122.33^{\mathrm{a}}$ & $126.10^{\mathrm{a}}$ & 6.01 & 0.061 \\
\hline
\end{tabular}

ment followed in the LPS + Arg treatment and then in the saline and Arg treatments. The content of $\kappa$-CN was not influenced significantly by the treatments $(P>$ $0.05)$, whereas the contents of $\alpha_{\mathrm{S}_{2}} \mathrm{CN}$ and $\beta-\mathrm{CN}$ were decreased significantly in the LPS-challenged cows $(P$ $<0.05)$ compared with the saline infusion. Lactalbumin content was greatest $(P<0.05)$ in the LPS treatment followed in the LPS + Arg treatment and then in the saline and Arg treatments. The content of IgG was not modified by any of the treatments, whereas the contents of $\operatorname{IgA}$ and $\operatorname{IgM}$ were increased significantly in the LPS treatment compared with the saline treatment.

Serum Cytokines and LipopolysaccharideBinding Protein. Lipopolysaccharide infusion significantly increased the serum concentrations of IL-1 $\beta$,
IL-6, TNF- $\alpha$, iNOS, and LBP $(P<0.05)$ compared with the saline treatment. The LPS + Arg treatment significantly decreased the IL-6 and iNOS levels $(P<$ $0.05)$ and tended $(P=0.075)$ to decrease LBP level compared with the LPS treatment (Table 4).

\section{Blood Metabolites}

As shown in Table 5, the concentrations of serum ALT, glucose, and urea were not influenced by different treatments $(P>0.05)$. The LPS treatment significantly decreased the WBC compared with the saline treatment $(P<0.05)$, and the WBC of Arg and LPS + Arg treatments were in between Arg and LPS treatments. The serum TP of LPS treatment was significantly lower

Table 4. Effects of jugular Arg infusion on cytokines, inducible nitric oxide synthase (iNOS), and lipopolysaccharide-binding protein (LBP) during LPS-induced inflammation of lactating cows

\begin{tabular}{|c|c|c|c|c|c|c|}
\hline \multirow[b]{2}{*}{ Item } & \multicolumn{4}{|c|}{ Experimental treatment ${ }^{1}$} & \multirow[b]{2}{*}{ SEM } & \multirow[b]{2}{*}{$P$-value ${ }^{2}$} \\
\hline & Saline & $\operatorname{Arg}$ & LPS & LPS + Arg & & \\
\hline \multicolumn{7}{|l|}{ Pre-infusion $^{3}$} \\
\hline IL-1 $\beta(\mathrm{pg} / \mathrm{mL})$ & 179.60 & 181.24 & 182.76 & 183.19 & 4.43 & 0.466 \\
\hline IL-6 (pg/mL) & 67.78 & 66.05 & 68.84 & 67.92 & 2.51 & 0.325 \\
\hline TNF- $\alpha^{4}(\mathrm{pg} / \mathrm{mL})$ & 65.42 & 63.87 & 64.73 & 66.76 & 1.59 & 0.118 \\
\hline \multicolumn{7}{|l|}{ Infusion } \\
\hline IL-1 $\beta(\mathrm{pg} / \mathrm{mL})$ & $171.28^{\mathrm{c}}$ & $184.31^{\mathrm{bc}}$ & $206.72^{\mathrm{a}}$ & $191.89^{\mathrm{ab}}$ & 6.43 & 0.007 \\
\hline IL-6 $(\mathrm{pg} / \mathrm{mL})$ & $63.90^{\mathrm{b}}$ & $69.00^{\mathrm{b}}$ & $86.39^{\mathrm{a}}$ & $73.43^{\mathrm{b}}$ & 6.68 & 0.019 \\
\hline TNF- $\alpha(\mathrm{pg} / \mathrm{mL})$ & $67.31^{\mathrm{b}}$ & $68.53^{\mathrm{b}}$ & $77.48^{\mathrm{a}}$ & $73.22^{\mathrm{ab}}$ & 3.08 & 0.014 \\
\hline $\operatorname{iNOS}(\mathrm{U} / \mathrm{mL})$ & $17.31^{\mathrm{c}}$ & $17.32^{\mathrm{c}}$ & $25.14^{\mathrm{a}}$ & $22.06^{\mathrm{b}}$ & 0.53 & $<0.001$ \\
\hline $\mathrm{LBP}(\mu \mathrm{mol} / \mathrm{L})$ & $174.76^{\mathrm{b}}$ & $175.48^{\mathrm{b}}$ & $195.63^{\mathrm{a}}$ & $183.58^{\mathrm{ab} *}$ & 8.44 & 0.075 \\
\hline
\end{tabular}

${ }^{\mathrm{a}-\mathrm{c}}$ Values within a row with different superscripts differed $(P<0.05)$ or tended $\left({ }^{*} P<0.10\right)$ to differ from the LPS treatment.

${ }^{1}$ Treatments: control (saline), Arg $(3 \mathrm{~g} / \mathrm{h})$, LPS $(0.033 \mu \mathrm{g} / \mathrm{kg}$ per h), and LPS $+\operatorname{Arg}(0.033 \mu \mathrm{g} / \mathrm{kg}$ per h of LPS and $3 \mathrm{~g} / \mathrm{h}$ of $\mathrm{Arg})$.

${ }^{2}$ Probability of a difference among the 4 treatments: control (saline), Arg, LPS, and LPS + Arg.

${ }^{3}$ Pre-infusion: samples collected at the last $2 \mathrm{~d}$ of each noninfusion period preceding each infusion period.

${ }^{4} \mathrm{TNF}-\alpha=$ tumor necrosis factor 
Table 5. Effects of jugular Arg infusion on serum metabolite profiles during LPS-induced inflammation of lactating cows

\begin{tabular}{|c|c|c|c|c|c|c|}
\hline \multirow[b]{2}{*}{ Item } & \multicolumn{4}{|c|}{ Experimental treatment ${ }^{1}$} & \multirow[b]{2}{*}{ SEM } & \multirow[b]{2}{*}{$P$-value ${ }^{2}$} \\
\hline & Saline & Arg & LPS & $\mathrm{LPS}+\mathrm{Arg}$ & & \\
\hline$\overline{\mathrm{WBC}\left(10^{9} / \mathrm{L}\right)}$ & $9.36^{\mathrm{b}}$ & $10.68^{\mathrm{ab}}$ & $12.73^{\mathrm{a}}$ & $11.76^{\mathrm{ab}}$ & 0.82 & 0.041 \\
\hline $\mathrm{TP}(\mathrm{g} / \mathrm{L})$ & $77.76^{\mathrm{a}}$ & $80.01^{\mathrm{a}}$ & $71.56^{\mathrm{b}}$ & $76.93^{\mathrm{a}}$ & 1.09 & 0.006 \\
\hline $\operatorname{ALT}(\mathrm{g} / \mathrm{L})$ & 13.51 & 11.63 & 14.81 & 14.40 & 0.75 & 0.481 \\
\hline $\operatorname{AST}(\mathrm{g} / \mathrm{L})$ & $70.38^{\mathrm{b}}$ & $74.86^{\mathrm{b}}$ & $106.36^{\mathrm{a}}$ & $88.50^{\mathrm{ab}}$ & 9.82 & 0.049 \\
\hline Glucose $(\mathrm{mmol} / \mathrm{L})$ & 2.75 & 2.82 & 2.85 & 2.69 & 0.20 & 0.846 \\
\hline Urea (mmol/L) & 3.55 & 3.41 & 4.23 & 3.47 & 0.39 & 0.193 \\
\hline
\end{tabular}

a,b Values within a row with different superscripts differed $(P<0.05)$.

${ }^{1}$ Treatments: control (saline), Arg $(3 \mathrm{~g} / \mathrm{d})$, LPS $(0.033 \mu \mathrm{g} / \mathrm{kg}$ per h), and LPS $+\operatorname{Arg}(0.033 \mu \mathrm{g} / \mathrm{kg}$ per h of LPS and $3 \mathrm{~g} / \mathrm{h}$ of Arg).

${ }^{2}$ Probability of a difference among the 4 treatments: control (saline), Arg, LPS, and LPS + Arg.

${ }^{3} \mathrm{WBC}=$ white blood cells; $\mathrm{TP}=$ total protein; ALT $=$ alanine aminotransferase; AST $=$ aspartate aminotransferase.

than that of the saline, Arg, and LPS + Arg treatments $(P<0.05)$. In contrast, serum AST of the LPS treatment was significantly greater $(P<0.05)$ compared with that of the saline and Arg treatments.

\section{Plasma Amino Acids}

The concentrations of plasma AA are shown in Table 6. The concentrations of Gly, Arg, Thr, Ala, Val, Met, Ile, Leu, Phe, Lys, and total free amino acid (TFAA) were significantly decreased in the LPS-challenged treatment $(P<0.05)$ compared with the saline treatment. In the LPS + Arg treatment, the concentrations of Gly, Arg, Thr, Ile, Leu, Phe, and TFAA significantly increased $(P<0.05)$ compared with the LPS treatment, and no significant difference in either measure was found when compared with the saline treatment. The concentrations of plasma Asp, Glu, Ser, His, Pro, Try, and Cys were not modified by any of the treatments.

Table 6. Effects of jugular Arg infusion on plasma AA profiles $(\mu \mathrm{g} / \mathrm{mL})$ during LPS-induced inflammation of lactating cows

\begin{tabular}{|c|c|c|c|c|c|c|}
\hline \multirow[b]{2}{*}{ Item } & \multicolumn{4}{|c|}{ Experimental treatment ${ }^{1}$} & \multirow[b]{2}{*}{ SEM } & \multirow[b]{2}{*}{$P$-value ${ }^{2}$} \\
\hline & Saline & $\operatorname{Arg}$ & LPS & LPS + Arg & & \\
\hline Asp & 0.64 & 0.76 & 0.73 & 0.84 & 0.09 & 0.139 \\
\hline Glu & 7.05 & 7.30 & 6.05 & 7.24 & 0.70 & 0.501 \\
\hline Ser & 6.34 & 7.42 & 4.40 & 7.39 & 4.58 & 0.851 \\
\hline Gly & $12.28^{\mathrm{a}}$ & $14.15^{\mathrm{a}}$ & $7.77^{\mathrm{b}}$ & $11.85^{\mathrm{a}}$ & 1.40 & 0.006 \\
\hline His & 28.35 & 21.91 & 31.60 & 29.52 & 6.30 & 0.470 \\
\hline $\operatorname{Arg}$ & $15.18^{\mathrm{b}}$ & $20.47^{\mathrm{a}}$ & $9.94^{\mathrm{c}}$ & $13.64^{\mathrm{ab}}$ & 2.23 & 0.003 \\
\hline Thr & $6.65^{\mathrm{a}}$ & $6.75^{\mathrm{a}}$ & $4.86^{\mathrm{b}}$ & $6.80^{\mathrm{a}}$ & 0.54 & 0.141 \\
\hline Ala & $12.70^{\mathrm{a}}$ & $12.94^{\mathrm{a}}$ & $10.12^{\mathrm{b}}$ & $11.56^{\mathrm{ab}}$ & 0.83 & 0.069 \\
\hline Pro & 8.80 & 7.50 & 10.43 & 8.14 & 1.29 & 0.369 \\
\hline Tyr & 5.99 & 7.87 & 7.28 & 7.50 & 0.64 & 0.224 \\
\hline Val & $18.56^{\mathrm{ab}}$ & $21.83^{\mathrm{a}}$ & $13.68^{\mathrm{c}}$ & $16.88^{\mathrm{bc}}$ & 1.14 & 0.004 \\
\hline Met & $2.11^{\mathrm{ab}}$ & $2.95^{\mathrm{a}}$ & $1.30^{\mathrm{b}}$ & $2.05^{\mathrm{ab}}$ & 0.31 & 0.045 \\
\hline Cys & 0.92 & 1.29 & 1.29 & 1.20 & 0.23 & 0.526 \\
\hline Ile & $11.79^{\mathrm{a}}$ & $12.30^{\mathrm{a}}$ & $8.82^{\mathrm{b}}$ & $10.80^{\mathrm{a}}$ & 0.52 & 0.001 \\
\hline Leu & $14.34^{\mathrm{a}}$ & $15.33^{\mathrm{a}}$ & $10.35^{\mathrm{b}}$ & $13.33^{\mathrm{a}}$ & 0.95 & 0.011 \\
\hline Phe & $8.81^{\mathrm{a}}$ & $8.83^{\mathrm{a}}$ & $7.00^{\mathrm{b}}$ & $8.62^{\mathrm{a}}$ & 0.53 & 0.081 \\
\hline Lys & $8.08^{\mathrm{ab}}$ & $9.20^{\mathrm{a}}$ & $5.92^{\mathrm{b}}$ & $6.76^{\mathrm{b}}$ & 0.78 & 0.035 \\
\hline TFAA $^{3}$ & $169.70^{\mathrm{a}}$ & $179.66^{\mathrm{a}}$ & $142.48^{\mathrm{b}}$ & $167.13^{\mathrm{a}}$ & 4.81 & $<0.001$ \\
\hline
\end{tabular}

${ }^{a-c}$ Values within a row with different superscripts differed $(P<0.05)$.

${ }^{1}$ Treatments: control (saline), Arg $(3 \mathrm{~g} / \mathrm{h})$, LPS $(0.033 \mu \mathrm{g} / \mathrm{kg}$ per h), and LPS $+\operatorname{Arg}(0.033 \mu \mathrm{g} / \mathrm{kg}$ per h of LPS and $3 \mathrm{~g} / \mathrm{h}$ of Arg).

${ }^{2}$ Probability of a difference among the 4 treatments: control (saline), Arg, LPS, and LPS + Arg.

${ }^{3}$ Total free amino acids $($ TFAA $)=$ sum of Asp, Glu, Ser, Gly, His, Arg, Thr, Ala, Pro, Tyr, Val, Met, Cys, Ile, Leu, Phe, and Lys. 


\section{DISCUSSION}

In ruminants, substantial evidence indicates that a grain-based SARA challenge increases the content of free LPS in the rumen (Gozho et al., 2007; Nagaraja and Lechtenberg, 2007; Plaizier et al., 2008), and it has been reported that LPS translocation to the peripheral circulation occurs during SARA (Gozho et al., 2007). The accumulation of LPS in peripheral blood may cause inflammation. It is well known that inflammation events are characterized by eliciting and releasing a large number of pro-inflammatory cytokines, such as TNF- $\alpha$, IL-1 $\beta$, and IL-6 and synthesizing the acute phase proteins, such as LBP. Aspartate aminotransferase and ALT are the markers for hepatocellular injury and indicate the concentration of hepatic intracellular enzymes that have leaked into the circulation (Han et al., 2012). In our study, the LPS infusion treatment was used to establish an inflammatory model. The infusion dose of LPS was $0.2 \mu \mathrm{g} / \mathrm{kg}$ of BW by reference to Waldron et al. (2003) and Smith et al. (2015), and the time frame was modeled after Ning et al. (2018). The results indicated that LPS infusion remarkably increased serum IL-1 $\beta$, IL-6, TNF- $\alpha$, LBP, and AST. Therefore, jugular infusion LPS induced an inflammatory response and hepatocellular injury in our trial.

Arginine, a precursor for the synthesis of NO, polyamines, proline, and agmatine, is capable of improving DNA and protein synthesis to maintain the nitrogen balance and promoting the proliferation and apoptosis of immune system cells by converting to ornithine and polyamines during immune stress conditions. In addition, Arg also exerts its immunologic function by stimulating hormone releases, such as insulin and growth hormone. It has been proven to enhance the immune status in pigs (Tan et al., 2009), rats and mice (Sharma et al., 2004), and chickens (Tayade et al., 2006). However, little research has been focused on lactating dairy cows. Thus, a following trial that supplemented LPS-induced lactating dairy cows with Arg was conducted to investigate the effects of Arg on inflammatory response. The infusion dose of Arg was $18 \mathrm{~g} / \mathrm{d}$, which is based on $20 \%$ of the base value $(90 \mathrm{~g} / \mathrm{d}$, unpublished data determined by our group) of plasma Arg in the preparation period to alleviate inflammation.

\section{Feed Intake and Milk Performance}

The results of our study showed that DMI and milk yield were lower in the LPS-infusion cows than that in saline-infused treatment, which is in line with the previous studies (Zebeli et al., 2011). Milk yield was decreased by LPS as a result of decreased DMI and the increased energy demands of the immune system
(Bradford et al., 2015). Cows in the LPS + Arg treatment had a higher milk production that may be attributed to the high DMI.

In the current study, there was no effect on the percentage of milk protein in LPS treatment, but the milk protein yield was lower in LPS-infused dairy cows than that in other treatments. This is likely due to the difference of milk yield. It should be noted that there were differences in protein composition between LPSinfused dairy cows and other dairy cows. Casein is the major ingredient of milk protein, and it occupies approximately $80 \%$ of the total lactoprotein, with $\alpha-\mathrm{CN}$, $\beta-\mathrm{CN}$, and $\kappa-\mathrm{CN}$. We found that total casein content significantly decreased in LPS-infused dairy cows, and LPS + Arg treatment remarkably increased the total casein content (Table 3). This finding may be explained by the study that LPS inhibited the gene and protein expression of casein synthesis in dairy cows (Zhang et al., 2016). During an in vitro study, it has been reported that Arg increased the synthesis of casein in bovine mammary epithelial cells, which may be attributed to an increase in genes' expression of the activation of mammalian target of rapamycin (mTOR), Janus kinase 2 (JAK2), and signal transducer and activator of transcription 5 (STAT5; Wang et al., 2014). Moreover, lactalbumin was higher in cows infused with LPS compared with others. Higher lactalbumin for LPS treatment is likely due to more immune protein was synthetized in response to the inflammation, which is related to the immune state of dairy cows. Lactalbumin of cows infused with LPS + Arg was intermediated between the LPS and saline treatments. It demonstrated that the immune state of dairy cows might have been relieved partially.

Several studies have indicated that intraperitoneal infusion of LPS or intravenous administration of TNF- $\alpha$ or IL-1 notably lowers lipogenesis in the mammary gland of lactating rats (Argilés et al., 1989; López-Soriano and Williamson, 1994). Additionally, LPS was shown to suppress the activity of lipoprotein lipase (Dong et al., 2011) and TNF- $\alpha$ was also proven to inhibit the activity of lipoprotein lipase (Argilés et al., 1989), which is the key enzyme involved in releasing fatty acids from circulating lipoproteins for mammary gland uptake. In this study, we found LPS infusion markedly increased the concentration of IL- $1 \beta$ and TNF- $\alpha$, which may be the reason for the decrease in milk fat yield. However, the LPS + Arg treatment increased the milk fat yield. It is possible that Arg might indirectly affect milk fat synthesis through the decrease in pro-inflammatory cytokines.

Consistent with our observation, Wellnitz et al. (2011) and Vernay et al. (2012) observed the increase in milk SCC of dairy cows infused with LPS. However, 
Arg might improve this status in our study. Milk urea nitrogen is considered to be a useful tool for monitoring the nitrogen utilization efficiency of dairy cows (Godden et al., 2001). High MUN concentrations are indicative of decreased whole-body $\mathrm{N}$ utilization efficiency (Broderick et al., 2008), suggesting that dietary protein was not used to synthesize protein (i.e., milk and muscle). Our results indicated that MUN was not affected by the treatments, which means LPS and Arg infusion have no effect on the nitrogen utilization efficiency of lactating dairy cows. Vitamins, minerals, protein, and lactose make SNF, which is the most essential part of the milk. The percentage of SNF has no significant change, which may be attributed to the unchanged percentage of primary nutrients, such as proteins and lactose.

\section{Response of Serum Cytokines and LBP to Arginine Infusion}

The results of the present study indicate that during inflammatory status, Arg infusion attenuated the increase in serum primary pro-inflammation IL-6 triggered by LPS (Table 4). Lipopolysaccharide-binding protein, an acute phase protein, interacts with LPS (Sriskandan and Altmann, 2008). Bannerman et al. (2003) and Khafipour et al. (2009) reported that LPS significantly increased the LBP. Consistent with this observation, we observed the increase in LBP of dairy cows infused with LPS. At the same time, we found that the LPS + Arg treatment tended to decrease LBP, which may be associated with the alleviation of the inflammatory response by Arg to a certain extent, and the secretion of acute protein LBP decreased accordingly. In addition, LPS can also activate iNOS and then release of cytotoxic nitric oxide produced by mesangial cells to destroy pathogens (Lee et al., 2002). Similarly, MacNaul and Hutchinson (1993) reported that LPS induced the increase in iNOS. In agreement with these findings, LPS-infused cows had the highest concentration of serum iNOS compared with that in Arg-infused cows in our trial. Arginine reduced iNOS during stress status, mainly because Arg was preferentially catalyzed to ornithine by arginase to exhibit immune function (Tadié et al., 2013). This result was also observed by Wijnands et al. (2012).

\section{Blood Metabolite Responses to Arginine Infusion}

Total WBC is a commonly measured index for the immune status in animals (Watanabe et al., 2000). The LPS treatment increased the WBC compared with the saline treatment in the current study. In agreement with our finding, Oh et al. (2017) reported that WBC was increased by LPS challenge compared with the pre-challenge. Notably, the WBC Arg and LPS + Arg treatments were in between Arg and LPS treatments, but the values are in the normal range $(4,000-12,000$ per microliter; Kramer, 2000). In agreement with our findings, Stechmiller and Childress (2004) found that Arg stimulated the production of WBC in critically ill patients. As we know, adrenal hormones affect blood leukocyte distribution (Geffner et al., 1995). Therefore, an increase in corticosterone level was associated with a decrease in the number of total WBC. Additionally, Arg could decrease corticosterone in mice (Repetto et al., 2006) and finishing pigs (Ma et al., 2010). Thus, it is possible that Arg infusion increased the number of leukocytes partially by decreasing the cortisol level.

Glucose, energy yielding metabolites, and urea were unchanged through Arg infusion in our study, which was in line with the finding of Ma et al. (2010). Similarly, Tian et al. (2017) reported that the removal of Arg supplied from jugular-infused AA mixture had no effect on plasma glucose and urea in lactating dairy cows. This may be attributed to the role of homeostasis in peripheral blood.

\section{Changes in Plasma Amino Acids}

We also determined the concentration of AA in plasma. The results showed that LPS infusion remarkably decreased plasma Gly, Arg, Ala, Val, Met, Ile, Leu, Lys, and TFAA. Similarly, Waggoner et al. (2009) found that LPS infusion decreased the plasma Lys, Met, Leu, Ile, Phe, Trp, Ser, Glu, Ala, Gln, Val, and Thr. This result may indicate that inflammation strengthened the utilization of AA that were mainly used for immune reaction. Under an immune stress state, plasma AA are preferred to synthesize acute phase proteins rather than body tissue proteins. Furthermore, acute phase proteins contain more Phe, Trp, Lys, Cys, and Ser (Reeds and Jahoor, 2001). Threonine is an important component of the $\operatorname{IgG}, \operatorname{IgA}$, and $\operatorname{IgM}$ (Tenenhouse and Deutsch, 1966). Calder (2006) reported that branched-chain AA (Leu, Val, and Ile) are also related to the generation of antibodies. Therefore, these may be the reasons for the decrease of these AA in plasma. However, in this study, LPS + Arg treatment not only increased plasma Arg but also attenuated the decrease in plasma Gly, Ala, Val, Met, Ile, Leu, Lys, and TFAA. This may be associated with Arg-alleviated inflammation, decreased consumption of plasma free AA, and improved AA disorders.

\section{CONCLUSIONS}

The results from this study implied that jugular Arg infusion exerts positive effects on attenuating inflam- 
matory stress and improving the immunity status of lactating dairy cows with LPS-triggered inflammation. The alleviating effects of Arg on inflammation are associated with decreasing levels of serum IL-6, iNOS and LBP, and the improvement of the milk performance of lactating dairy cows.

\section{ACKNOWLEDGMENTS}

The authors acknowledge the funding received to conduct this study from the project funded by the Top Talent Award Plan of Yangzhou University (2016), National Key Basic Research Program of China (973 Program: 2011CB100803), NSFC (the National Natural Science Foundation of China, Beijing; Grant No. 31572429), and Priority Academic Program Development of Jiangsu Higher Education Institutions (PAPD, China).

\section{REFERENCES}

Aditya, S., E. Humer, P. Pourazad, R. Khiaosaard, J. Huber, and Q. Zebeli. 2017. Intramammary infusion of Escherichia coli lipopolysaccharide negatively affects feed intake, chewing, and clinical variables, but some effects are stronger in cows experiencing subacute rumen acidosis. J. Dairy Sci. 100:1363-1377.

Ametaj, B. N., Q. Zebeli, and S. Iqbal. 2010. Nutrition, microbiota, and endotoxin-related diseases in dairy cows. Rev. Bras. Zootec. 39(Suppl):433-444.

Argilés, J. M., F. J. Lopez-Soriano, R. D. Evans, and D. H. Williamson. 1989. Interleukin-1 and lipid metabolism in the rat. Biochem. J. 259:673-678.

Bannerman, D. D., M. J. Paape, W. R. Hare, and E. J. Sohn. 2003. Increased levels of LPS-binding protein in bovine blood and milk following bacterial lipopolysaccharide challenge. J. Dairy Sci. 86:3128-3137.

Bilal, M. S., J. A. Abaker, Z. U. Aabdin, T. Xu, H. Dai, K. Zhang, X. Liu, and X. Shen. 2016. Lipopolysaccharide derived from the digestive tract triggers an inflammatory response in the uterus of mid-lactating dairy cows during SARA. BMC Vet. Res. 12:284.

Bradford, B. J., K. Yuan, J. K. Farney, L. K. Mamedova, and A. J. Carpenter. 2015. Invited review: Inflammation during the transition to lactation: New adventures with an old flame. J. Dairy Sci. 98:6631-6650.

Broderick, G. A., M. J. Stevenson, R. A. Patton, N. E. Lobos, and J. J. Olmos Colmenero. 2008. Effect of supplementing rumen-protected methionine on production and nitrogen excretion in lactating dairy cows. J. Dairy Sci. 91:1092-1102.

Calder, P. C. 2006. Branched-chain amino acids and immunity. J. Nutr. 136(Suppl):288S.

Calkins, C. M., D. D. Bensard, J. K. Heimbach, X. Meng, B. D. Shames, E. J. Pulido, and M. I. R. Jr. 2001. L-arginine attenuates lipopolysaccharide-induced lung chemokine production. Am. J. Physiol. Lung Cell. Mol. Physiol. 280:L400-L408.

Chinese Academy of Sciences. 2013. Standard for management of animal experiments. Beijing, China.

Doepel, L., and H. Lapierre. 2011. Deletion of arginine from an abomasal infusion of amino acids does not decrease milk protein yield in Holstein cows. J. Dairy Sci. 94:864-873.

Dong, G., S. Liu, Y. Wu, C. Lei, J. Zhou, and S. Zhang. 2011. Dietinduced bacterial immunogens in the gastrointestinal tract of dairy cows: Impacts on immunity and metabolism. Acta Vet. Scand. $53: 48$.
Emmanuel, D. G. V., S. M. Dunn, and B. N. Ametaj. 2008. Feeding high proportions of barley grain stimulates an inflammatory response in dairy cows. J. Dairy Sci. 91:606-614.

Geffner, J. R., A. S. Trevani, D. E. I. De, M. Diament, D. Klein, and M. Giordano. 1995. Involvement of nitric oxide in the regulation of peripheral blood leukocyte counts. J. Leukoc. Biol. 58:391-394.

Godden, S. M., K. D. Lissemore, D. F. Kelton, K. E. Leslie, J. S. Walton, and J. H. Lumsden. 2001. Relationships between milk urea concentrations and nutritional management, production, and economic variables in Ontario dairy herds. J. Dairy Sci. 84:1128-1139.

Gozho, G. N., D. O. Krause, and J. C. Plaizier. 2007. Ruminal lipopolysaccharide concentration and inflammatory response during grain-induced subacute ruminal acidosis in dairy cows. J. Dairy Sci. 90:856-866.

Han, N., H. Soe, and A. Htet. 2012. Determinants of abnormal liver function tests in diabetes patients in Myanmar. Int. J. Exp. Diabetes Res. 1:36-41.

Jiang, J., D. Shi, X. Q. Zhou, Y. Hu, L. Feng, Y. Liu, W. D. Jiang, and Y. Zhao. 2015. In vitro and in vivo protective effect of arginine against lipopolysaccharide induced inflammatory response in the intestine of juvenile Jian carp (Cyprinus carpio var. Jian). Fish Shellfish Immunol. 42:457-464.

Khafipour, E., D. O. Krause, and J. C. Plaizier. 2009. A grain-based subacute ruminal acidosis challenge causes translocation of lipopolysaccharide and triggers inflammation. J. Dairy Sci. 92:10601070.

Kobayashi, K., S. Oyama, A. Numata, M. M. Rahman, and H. Kumura. 2013. Lipopolysaccharide disrupts the milk-blood barrier by modulating claudins in mammary alveolar tight junctions. PLoS One 8:e62187.

Kramer, J. W. 2000. Normal hematology of cattle, sheep, and goats. Pages 1075-1084 in Schalm's Veterinary Hematology. B. Feldman, J. Zinkl, and N. Jain, ed. Lippincott, Philadelphia, PA.

Kvidera, S. K., E. A. Horst, M. Abuajamieh, E. J. Mayorga, M. V. Fernandez, and L. H. Baumgard. 2017. Glucose requirements of an activated immune system in lactating Holstein cows. J. Dairy Sci. 100:2360-2374.

Lee, H. Y., H. J. Noh, J. G. Gang, Z. G. Xu, H. J. Jeong, S. W. Kang, K. H. Choi, and D. S. Han. 2002. Inducible nitric oxide synthase (iNOS) expression is increased in lipopolysaccharide (LPS)-stimulated diabetic rat glomeruli: Effect of ACE inhibitor and angiotensin II receptor blocker. Yonsei Med. J. 43:183-192.

López-Soriano, F. J., and D. H. Williamson. 1994. Acute effects of endotoxin (lipopolysaccharide) on tissue lipid metabolism in the lactating rat. The role of delivery of intestinal glucose. Mol. Cell. Biochem. 141:113-120.

Luiking, Y. C., M. Poeze, G. Ramsay, and N. E. Deutz. 2009. Reduced citrulline production in sepsis is related to diminished de novo arginine and nitric oxide production. Am. J. Clin. Nutr. 89:142-152.

Ma, X., Y. Lin, Z. Jiang, C. Zheng, G. Zhou, D. Yu, T. Cao, J. Wang, and F. Chen. 2010. Dietary arginine supplementation enhances antioxidative capacity and improves meat quality of finishing pigs. Amino Acids 38:95-102.

MacNaul, K. L., and N. I. Hutchinson. 1993. Differential expression of iNOS and cNOS mRNA in human vascular smooth muscle cells and endothelial cells under normal and inflammatory conditions. Biochem. Biophys. Res. Commun. 196:1330-1334.

Mohamed A. M., A. G. Doooa, E. H. Elasyed, E. Bassiouny, and E. Mohamed. 2015. L-arginine down-regulated TNF- $\alpha$ gene in LPS induced inflammation in experimental rats. EJPMR 2:01-19.

Moore, S., and W. H. Stein. 1954. Procedure for the chromatographic determination of amino acids on four per cent cross-linked sulfonated polystyrene resins. J. Biol. Chem. 211:893-906.

Nagaraja, T. G., and K. F. Lechtenberg. 2007. Acidosis in feedlot cattle. Vet. Clin. North Am. Food Anim. Pract. 23:333-350.

Ning, L. T., G. Z. Dong, C. Ao, K. Erdene, F. Q. Zhang, J. Wen, and T. L. Zhang. 2018. Effects of continuous low dose infusion of lipopolysaccharide on inflammatory responses, milk production and milk quality in dairy cows. J. Anim. Physiol. Anim. Nutr. (Berl.) https://doi.org/10.1111/jpn.12737. 
NRC. 2001. Nutrient Requirements of Dairy Cattle. 7th rev. ed. Natl. Acad. Sci. Washington, DC.

Oh, J., M. Harper, F. Giallongo, D. M. Bravo, E. H. Wall, and A. N. Hristov. 2017. Effects of rumen-protected Capsicum oleoresin on immune responses in dairy cows intravenously challenged with lipopolysaccharide. J. Dairy Sci. 100:1902-1913.

Pi, D., Y. Liu, H. Shi, S. Li, J. Odle, X. Lin, H. Zhu, F. Chen, Y. Hou, and W. Leng. 2014. Dietary supplementation of aspartate enhances intestinal integrity and energy status in weanling piglets after lipopolysaccharide challenge. J. Nutr. Biochem. 25:456-462.

Plaizier, J. C., E. Khafipour, S. Li, G. N. Gozho, and D. O. Krause. 2012. Subacute ruminal acidosis (SARA), endotoxins and health consequences. Anim. Feed Sci. Technol. 172:9-21.

Plaizier, J. C., D. O. Krause, G. N. Gozho, and B. W. Mcbride. 2008. Subacute ruminal acidosis in dairy cows: The physiological causes, incidence and consequences. Vet. J. 176:21-31.

Reeds, P. J., and F. Jahoor. 2001. The amino acid requirements of disease. Clin. Nutr. 20:15-22.

Repetto, E. M., V. Pannunzio, F. Astort, C. C. Martinez, M. B. Moreno, O. P. Pignataro, and C. B. Cymeryng. 2006. Characterization of L-arginine transport in adrenal cells: Effect of ACTH. Am. J. Physiol. Endocrinol. Metab. 291:E291-E297.

Sato, S. 2015. Subacute ruminal acidosis (SARA) challenge, ruminal condition and cellular immunity in cattle. Jpn. J. Vet. Res. 63(Suppl. 1):S25-S36.

Satriano, J. 2004. Arginine pathways and the inflammatory response: Interregulation of nitric oxide and polyamines: Review article. Amino Acids 26:321-329.

Sharma, K. K., P. K. Mediratta, K. H. Reeta, and P. Mahajan. 2004. Effect of L-arginine on restraint stress induced modulation of immune responses in rats and mice. Pharmacol. Res. 49:455-460.

Smith, D. J., W. L. Shelver, R. E. Baynes, L. Tell, R. Gehring, M. Li, T. Dutko, J. W. Schroeder, G. Herges, and J. E. Riviere. 2015. Excretory, secretory, and tissue residues after label and extra-label administration of flunixin meglumine to saline- or lipopolysaccharide-exposed dairy cows. J. Agric. Food Chem. 63:4893-4901.

Sriskandan, S., and D. Altmann. 2008. The immunology of sepsis. J. Pathol. 214:211-223

Stechmiller, J. K., and B. T. Childress. 2004. Arginine immunonutrition in critically ill patients: A clinical dilemma. Am. J. Crit. Care $13: 17-23$.

Tadié, J. M., L. Cynober, V. Peigne, A. Caumontprim, N. Neveux, A. Gey, E. Guerot, J. L. Diehl, J. Y. Fagon, and E. Tartour. 2013. Arginine administration to critically ill patients with a low nitric oxide fraction in the airways: A pilot study. Intensive Care Med. 39:1663-1665.

Tan, B., X. G. Li, X. F. Kong, R. L. Huang, R. Zheng, K. Yao, Z. Y. Deng, M. Y. Xie, I. Shinzato, and Y. L. Yin. 2009. Dietary L-arginine supplementation enhances the immune status in earlyweaned piglets. Amino Acids 37:323-331.

Tan, J., S. Liu, Y. Guo, T. J. Applegate, and S. D. Eicher. 2014. Dietary L-arginine supplementation attenuates lipopolysaccharideinduced inflammatory response in broiler chickens. Br. J. Nutr. 111:1394-1404.

Tayade, C., T. N. Jaiswal, S. C. Mishra, and M. Koti. 2006. L-arginine stimulates immune response in chickens immunized with intermediate plus strain of infectious bursal disease vaccine. Vaccine 24:552-560.

Tenenhouse, H. S., and H. F. Deutsch. 1966. Some physical-chemical properties of chicken $\gamma$-globulins and their pepsin and papain digestion products. Immunochemistry 3:11-20.

Tian, W., H. R. Wang, T. Y. Wu, L. Y. Ding, R. Zhao, E. Khas, C. F. Wang, F. Q. Zhang, F. Y. Mi, and L. Wang. 2017. Milk protein re- sponses to balanced amino acid and removal of Leucine and Arginine supplied from jugular-infused amino acid mixture in lactating dairy cows. J. Anim. Physiol. Anim. Nutr. (Berl.) 101:e278-e287.

Vernay, M. C., O. Wellnitz, L. Kreipe, H. A. van Dorland, and R. M Bruckmaier. 2012. Local and systemic response to intramammary lipopolysaccharide challenge during long-term manipulated plasma glucose and insulin concentrations in dairy cows. J. Dairy Sci. 95:2540-2549.

Waggoner, J. W. C. A. Löest, J. L. Turner, C. P. Mathis, and D. M. Hallford. 2009. Effects of dietary protein and bacterial lipopolysaccharide infusion on nitrogen metabolism and hormonal responses of growing beef steers. J. Anim. Sci. 87:3656-3668.

Waldron, M. R., T. Nishida, B. J. Nonnecke, and T. R. Overton. 2003 Effect of lipopolysaccharide on indices of peripheral and hepatic metabolism in lactating cows. J. Dairy Sci. 86:3447-3459.

Wang, M., B. Xu, H. Wang, D. Bu, J. Wang, and J. J. Loor. 2014. Effects of Arginine concentration on the in vitro expression of Casein and mTOR pathway related genes in mammary epithelial cells from dairy cattle. PLoS One 9:e95985.

Watanabe, A., Y. Yagi, H. Shiono, and Y. Yokomizo. 2000. Effect of intramammary infusion of tumour necrosis factor- $\alpha$ on milk protein composition and induction of acute-phase protein in the lactating cow. J. Vet. Med. B Infect. Dis. Vet. Public Health 47:653-662.

Wellnitz, O., E. T. Arnold, and R. M. Bruckmaier. 2011. Lipopolysaccharide and lipoteichoic acid induce different immune responses in the bovine mammary gland. J. Dairy Sci. 94:5405-5412.

Wijnands, K. A. P., T. M. R. Castermans, M. P. J. Hommen, D. M. Meesters, and M. Poeze. 2015. Arginine and citrulline and the immune response in sepsis. Nutrients 7:1426-1463.

Wijnands, K. A. P., H. Vink, J. J. Briedé, E. E. V. Faassen, W. H. Lamers, W. A. Buurman, and M. Poeze. 2012. Citrulline a more suitable substrate than arginine to restore NO production and the microcirculation during endotoxemia. PLoS One 7:e37439.

Wu, G. 2013. Functional amino acids in nutrition and health. Amino Acids 45:407-411.

Wu, T., W. Chao, L. Ding, Y. Shen, H. Cui, M. Wang, and H. Wang. 2016. Arginine relieves the inflammatory response and enhances the casein expression in bovine mammary epithelial cells induced by lipopolysaccharide. Mediators Inflamm. 2016:9618795.

Zebeli, Q., and B. U. Metzlerzebeli. 2012. Interplay between rumen digestive disorders and diet-induced inflammation in dairy cattle. Res. Vet. Sci. 93:1099-1108.

Zebeli, Q., S. Sivaraman, S. M. Dunn, and B. N. Ametaj. 2011. Intermittent parenteral administration of endotoxin triggers metabolic and immunological alterations typically associated with displaced abomasum and retained placenta in periparturient dairy cows. J. Dairy Sci. 94:4968-4983.

Zhang, K., G. Chang, T. Xu, L. Xu, J. Guo, D. Jin, and X. Shen. 2016. Lipopolysaccharide derived from the digestive tract activates inflammatory gene expression and inhibits casein synthesis in the mammary glands of lactating dairy cows. Oncotarget 7:9652-9665.

Zhou, J., G. Dong, C. Ao, S. Zhang, M. Qiu, X. Wang, Y. Wu, K Erdene, L. Jin, and C. Lei. 2014. Feeding a high-concentrate corn straw diet increased the release of endotoxin in the rumen and pro-inflammatory cytokines in the mammary gland of dairy cows. BMC Vet. Res. 10:172

Zhu, H. L., Y. L. Liu, X. L. Xie, J. J. Huang, and Y. Q. Hou. 2013. Effect of L-arginine on intestinal mucosal immune barrier function in weaned pigs after Escherichia coli LPS challenge. Innate Immun. 19:242-252. 